\title{
Preempting the Arrival of the Brown Marmorated Stink Bug, Halyomorpha halys: Biological Control Options for Australia
}

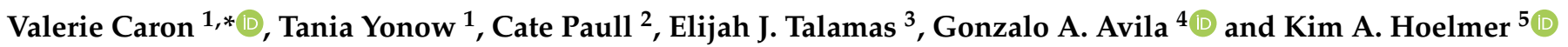 \\ 1 CSIRO, Health and Biosecurity, Black Mountain, Acton, ACT 2601, Australia; Tania.Yonow@csiro.au \\ 2 CSIRO, Agriculture and Food, Dutton Park, QLD 4102, Australia; Cate.Paull@csiro.au \\ 3 Florida Department of Agriculture and Consumer Services, Division of Plant Industry, Bureau of Entomology, \\ Nematology and Plant Pathology, Gainesville, FL 32608, USA; Elijah.Talamas@fdacs.gov \\ 4 The New Zealand Institute for Plant and Food Research Limited, Auckland 1025, New Zealand; \\ Gonzalo.Avila@plantandfood.co.nz \\ 5 USDA, Agriculture Research Service, Beneficial Insects Introduction Research Unit, Newark, DE 19713, USA; \\ kim.hoelmer@usda.gov \\ * Correspondence: Valerie.Caron@csiro.au; Tel.: +61-02-6218-3475
}

Citation: Caron, V.; Yonow, T.; Paull, C.; Talamas, E.J.; Avila, G.A.; Hoelmer, K.A. Preempting the Arrival of the Brown Marmorated Stink Bug, Halyomorpha halys: Biological Control Options for Australia. Insects 2021, 12, 581. https://doi.org/10.3390/ insects12070581

Academic Editor: Lukasz L. Stelinski

Received: 22 March 2021

Accepted: 21 June 2021

Published: 28 June 2021

Publisher's Note: MDPI stays neutral with regard to jurisdictional claims in published maps and institutional affiliations.

Copyright: () 2021 by the authors. Licensee MDPI, Basel, Switzerland. This article is an open access article distributed under the terms and conditions of the Creative Commons Attribution (CC BY) license (https:// creativecommons.org/licenses/by/ $4.0 /)$.
Simple Summary: The brown marmorated stink bug Halyomorpha halys (Stål) (Hemiptera: Pentatomidae) is native to Northeast Asia, but has become a serious invasive species in North America and Europe, causing major economic damage to crops. Halyomorpha halys has not established itself in Australia, but it has been intercepted several times at the border, therefore future incursions and establishment are likely. There are few control options for this species and biological control may be a useful management method in Australia. This study summarizes the literature on natural enemies of $H$. halys in its native and invaded ranges and prioritizes potential biological control agents that could be suitable for use in Australia. The results show two egg parasitoid species as the best candidates: Trissolcus japonicus (Ashmead) and Trissolcus mitsukurii (Ashmead) (Hymenoptera: Scelionidae). Because T. mitsukurii is already present in Australia, it offers the possibility of biological control that can be implemented rapidly.

Abstract: The brown marmorated stink bug Halyomorpha halys (Stål) (Hemiptera: Pentatomidae) is native to Northeast Asia, but has become a serious invasive species in North America and Europe, causing major damage to crops. While it has not established itself in Australia, it has been intercepted at the border several times, indicating that future incursions and establishment are a case of when, not if. Biological control is one of the few control options for this species and will be important for managing $H$. halys should it become established in Australia. Prioritizing species that could be used as biological control agents would ensure Australia is prepared. This study summarizes the literature on natural enemies of $H$. halys in its native and invaded ranges and prioritizes potential biological control agents of $H$. halys that could be used in Australia. Two egg parasitoid species were identified: Trissolcus japonicus (Ashmead) and Trissolcus mitsukurii (Ashmead) (Hymenoptera: Scelionidae). Future efforts to develop biological control should focus on T. mitsukurii, as it is already present in Australia. However, little is known about this species and further work is required to: (1) assess its potential effectiveness in parasitizing $H$. halys, (2) determine its current distribution and (3) host range in Australia.

Keywords: biocontrol; egg parasitoid; host range; Scelionidae; Trissolcus japonicus; Trissolcus mitsukurii

\section{Introduction}

The brown marmorated stink bug, Halyomorpha halys (Stål) (Hemiptera: Pentatomidae), is native to Northeast and East Asia (China, Japan, Korea, Taiwan) [1]. It is considered an occasional or sporadic pest in Asia, due to outbreaks in orchards and also during its overwintering period when large numbers can invade dwellings [1,2]. Halyomorpha 
halys was introduced accidentally to Europe, North America [3-5], and more recently South America (Chile), where it is now a serious invasive pest [6]. Halyomorpha halys is polyphagous and feeds on over 100 plant species, including orchard crops (e.g., apples, peaches, pears, grapes), grain crops (e.g., wheat, soybean, sorghum), vegetable crops (e.g., corn, eggplant, tomato, okra), and many ornamental trees (e.g., birch, maple, willow) [3,5]. While $H$. halys causes major economic damage where it has invaded, it also has social impacts, invading indoors in large numbers to overwinter and releasing an unpleasant smell when disturbed [7].

Although H. halys is not yet established in New Zealand or Australia, it has been intercepted several times at borders of both countries, with most interceptions in cargo [8,9]. Introduction risk is more pronounced between September to April, when H. halys is looking for overwintering locations and may advertently board cargo destined for Australasia $[10,11]$. The fact that it has not yet established is a testament to the effectiveness of strict biosecurity policies in both countries.

Despite the preventative measures in place, $H$. halys will likely become established in both Australia and New Zealand. Climatic modelling indicates the potential for establishment and distribution of $H$. halys to include east coast regions from northern to southern Australia [8]. Many of the regions that closely match the potential distribution of $H$. halys are where Australia and New Zealand grow high value agricultural crops, such as orchard fruits and vegetables $[8,12,13]$. Therefore, preparing for the arrival and establishment of H. halys is paramount.

Insecticides can provide short-term control of $H$. halys populations [14], although their efficacy has been found to vary with season and with age of the residue [15]. Growing concerns about non-target effects, the development of resistance to insecticides, and their toxicity to beneficial organisms mean that alternative management strategies should be developed $[15,16]$. One of these alternatives is biological control. Classical biological control aims at reunifying the target organism with co-evolved natural enemies that are lacking in the introduced range to maintain pest populations below damaging levels. Biological control programs have been instigated for H. halys in the United States and Europe [17-19], but on both continents these follow the discovery of adventive parasitoids [20-22]. In a world first, New Zealand has developed a preemptive biological control program against $H$. halys, including completion of risk assessment of the egg parasitoid Trissolcus japonicus (Ashmead) in containment. As a result, New Zealand Environmental Protection Authority (EPA) approved the conditional release of T. japonicus, in the event that a population of $H$. halys is detected $[23,24]$. Australia is now following similar steps by investigating biological control options for $H$. halys prior to its introduction.

Here, we review prior studies on $H$. halys parasitoids and use them to prioritize a list of potential biological control agents. Further, we make recommendations about additional information required before these species could be considered as effective biological control agents or pre-approved for release, should H. halys become established in Australia.

\section{Materials and Methods}

The Web of Science database was used to find relevant publications, using the following key words with "Halyomorpha halys" on 24 May 2021: natural enemies, biological control, parasitoid, predator, fungus, virus, and pathogen, yielding 380 publications. A total of 145 unique relevant publications were found as follows: Halyomorpha halys and natural enemies $(\mathrm{n}=94) ; H$. halys and biological control $(\mathrm{n}=131) ; H$. halys and parasitoids $(\mathrm{n}=103) ; H$. halys and predator $(\mathrm{n}=37) ;$ H. halys and fungus $(\mathrm{n}=6) ;$ H. halys and virus $(\mathrm{n}=2) ; H$. halys and pathogen $(\mathrm{n}=7)$.

Natural enemies were separated using their location (native range and invaded range of $H$. halys) and their type of action (predator, parasitoid, pathogen), the stage attacked (egg, nymph, adult), and their host specificity (monophagous, oligophagous, polyphagous). Host specificity was often unknown for a specific natural enemy. In these cases, information about the genus in general or family was used to estimate expected specificity. 
To identify and prioritize potential biological control agents for use in Australia, we focused on species found in the native range, since biological control agents are generally sourced from the native range. However, we also considered species found in the invaded range, (1) as these or their conspecifics might be of use in Australia and (2) as these may invade Australia of their own accord. We ranked species based on the following criteria: (1) being highly or narrowly specific to $H$. halys, and (2) being efficient at controlling $H$. halys The literature review was then extended to search for information about the species that satisfied criteria 1 and 2.

\section{Results}

\subsection{Natural Enemies of $H$. halys in Its Native Range}

Many natural enemies, including predators, parasitoids, and pathogens, are reported to attack H. halys in its native range (Table 1). Predators observed on H. halys in the native range are diverse and nonspecific, e.g., $[1,25,26]$. For example, spiders and the assassin bug Isyndus obscurus (Dallas) in the family Reduviidae can feed on nymphs and adults [25], while Orius sp. predatory bugs (Hemiptera: Anthocoridae) were observed feeding on $H$. halys eggs. The robber fly Astochia virgatipes Coquillett (Diptera: Asilidae) is also known to prey on H. halys, but the stage attacked was not specified [1]. Acrobat ants Crematogaster spp. (Hymenopera: Formicidae) were also shown to prey on nymphs in laboratory assays [27].

Egg parasitoids are commonly found attacking $H$. halys in its native range. In many instances, the name of the species is unknown, indicating gaps in the taxonomy of the natural enemies of $H$. halys. Several egg parasitoids from the order Hymenoptera were found on $H$. halys, mostly species from the genera Anastatus Motschulsky (Eupelmidae), Telenomus Haliday (Scelionidae), and Trissolcus Ashmead (Scelionidae) (Table 1). Six species of Trissolcus were found: Trissolcus japonicus, Trissolcus cultratus (Mayr), Trissolcus semistriatus (Nees von Esenbeck), Trissolcus comperei (Crawford), Trissolcus plautiae (Watanabe), and Trissolcus mitsukurii (Ashmead) (Table 1). Recent taxonomic revisions of Trissolcus in North America and the Palearctic have clarified the nomenclature and identification of Trissolcus spp. attacking H. halys, indicating that early identifications of T. halyomorphae were attributable to T. japonicus [13], and those of T. flavipes were more likely to have been T. cultratus [28]. The specimens reported as T. semistriatus were originally identified as T. nigripedius, which is now a junior synonym. It should be noted that T. semistriatus belongs to a complex of species and recent advances suggest that many past identifications were incorrect [29].

Other enemies found in the native range of $H$. halys may be secondary parasitoids or hyperparasitoids. Acroclisoides sp. (Hymenoptera: Pteromalidae) and Ooencyrtus sp. (Hymenoptera: Encyrtidae) were found in several studies $[1,16,25,30]$, but these are most likely hyperparasitoid species, as found in other studies [16,31-33], although not all Ooencyrtus sp. are hyperparasitoids [34]. These hyperparasitoids may have an impact on the populations of other pentatomid parasitoids, although extant literature suggests that they only occur in low numbers. For example, Ooencyrtus sp., which is likely a facultive hyperparasitoid, was only reared in less than $<1 \%$ of $H$. halys eggs [16].

Our review found only two reports of species attacking lifestages other than eggs of $H$. halys. Both were parasitic flies in the family Tachinidae: Bogosia sp. and Pentatomophaga latifascia (Villeneuve) were found parasitizing adults in Japan and China, respectively $[25,35]$. However, the host range of these two species is still unknown. [1]

Only three pathogens have been found infecting H. halys: a non-specific virus [36], the microsporidia Nosema maddoxi [37] and an entomopathogenic fungus that could affect nymphs and adults [38]. 
Table 1. Natural enemies of Halyomorpha halys found in the native range, showing host stage attacked, country of occurrence (including exotic locations), and host specificity level, including known hosts.

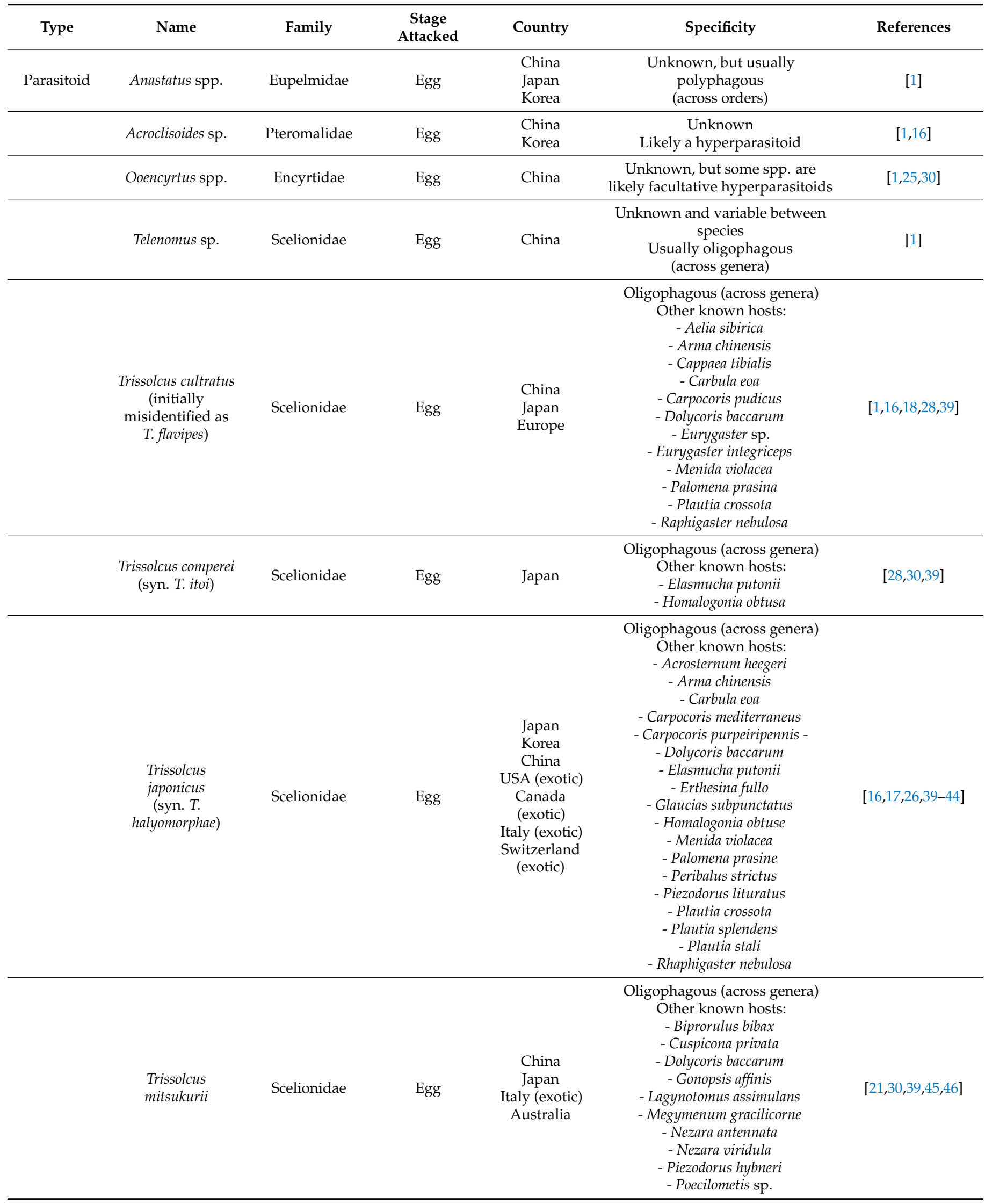


Table 1. Cont.

\begin{tabular}{|c|c|c|c|c|c|c|}
\hline Type & Name & Family & $\begin{array}{c}\text { Stage } \\
\text { Attacked }\end{array}$ & Country & Specificity & References \\
\hline & Trissolcus plautiae & Scelionidae & Egg & Japan & $\begin{array}{l}\text { Oligophagous (across genera) } \\
\text { Other known hosts: } \\
\text { - Glaucias subpunctatus } \\
\text { - Menidia violacea } \\
\text { - Plautia crossota } \\
\text { - Plautia stali }\end{array}$ & {$[16,30,39,42]$} \\
\hline & $\begin{array}{l}\text { Trissolcus } \\
\text { semistriatus (syn. } \\
\text { T. nigripedius) }\end{array}$ & Scelionidae & Egg & Korea & $\begin{array}{l}\text { Oligophagous (across genera) } \\
\text { Other known hosts: } \\
\text { - Dolycoris baccarum } \\
\text { - Piezodous hybneri } \\
\text { - Riptortus clavatus }\end{array}$ & [47] \\
\hline & Bogosia sp. & Tachinidae & Adult & Japan & Unknown & [25] \\
\hline & $\begin{array}{c}\text { Pentatomophaga } \\
\text { latifascia }\end{array}$ & Tachinidae & Adult & China & Unknown & [35] \\
\hline \multirow[t]{6}{*}{ Predator } & Arma chinensis & Pentatomidae & Unknown & China & Generalist & {$[1,26]$} \\
\hline & Astochia virgatipes & Asilidae & Unknown & China & Generalist & [1] \\
\hline & Orius sp. & Anthocoridae & Egg & China & Generalist & {$[1,26]$} \\
\hline & Isyndus obscurus & Reduviidae & Adult & Japan & Generalist & [25] \\
\hline & Spiders & & $\begin{array}{l}\text { Nymph } \\
\text { Adult }\end{array}$ & $\begin{array}{l}\text { China } \\
\text { Japan }\end{array}$ & Generalist & {$[25,26]$} \\
\hline & $\begin{array}{c}\text { Crematogaster } \\
\text { matsumurai and C. } \\
\text { osakensi }\end{array}$ & Formicidae & Nymph & Japan & Generalist & [27] \\
\hline Fungus & $\begin{array}{c}\text { Ophiocordyceps } \\
\text { nutans }\end{array}$ & & $\begin{array}{l}\text { Nymph } \\
\text { Adult }\end{array}$ & Japan & Low (across families) & {$[38]$} \\
\hline Pathogen & Nosema maddoxi & & & $\begin{array}{l}\text { China } \\
\text { South Korea } \\
\text { Republic of } \\
\text { Georgia } \\
\text { USA }\end{array}$ & $\begin{array}{l}\text { Other known hosts: } \\
\text { - Chinavia hilaris } \\
\text { - Euschistus servus } \\
\text { - Euschistus tristigmus }\end{array}$ & {$[37,48]$} \\
\hline Virus & $\begin{array}{l}\text { Plautia stali } \\
\text { intestine virus }\end{array}$ & & & Japan & Unknown & [36] \\
\hline
\end{tabular}

\subsection{Natural Enemies of H. halys in Its Invaded Range}

Following the accidental introduction of H. halys in Europe and North America, extensive surveys of indigenous natural enemies were conducted in the invaded range. Many generalist predators were shown to prey on different stages of $H$. halys.

In North America, eggs can be consumed by earwigs, katydids, crickets, grasshoppers, hemipterans (pentatomids and anthocorids), lacewings, and coccinellids [3,49-55], while nymphs and adults were preyed upon by wasps, wheel bugs, assassin bugs, and praying mantids [49,56,57], as well as members of several spider families [58]. Laboratory tests in Europe also showed predation by coccinellids, grasshoppers, earwigs, and hemipterans [59], and indicated that the generalist ant species Crematogaster scutellaris (Olivier) could potentially help control nymphal stages in Italy [60]. However, the impact of generalist predators on the overall $H$. halys populations in the field is unknown.

Many egg parasitoids were found in the invaded range, but overall parasitism levels remained low ( $<1$ to $15.1 \%$ ) [61,62] and variable (e.g., 0 to $59 \%$, based on parasitoid emergence across surveys) [49]. As in the native range, most egg parasitoids were from the genera Trissolcus, Telenomus, and Anastatus [49,63-76], but some studies also recovered Ooencyrtus spp. [77,78], with at least one species not considered a hyperparasitoid [34]. While none of these genera are known for their high host specificity, Trissolcus and Telenomus found on $H$. halys show a narrower host range than Anastatus [49]. Prevalence of each parasitoid was related to habitat type [49]. Three species of egg parasitoids known in the 
native range of $H$. halys are also found in the invaded range: Trissolcus cultratus is also native to Europe [28], while T. japonicus and T. mitsukurii have adventive populations. Trissolcus japonicus is now found in North America and Europe [21,44,75,79], while T. mitsukurii is found in Italy [21,62], with their distribution ranges predicted to increase [13].

A hyperparasitoid, Acroclisoides sinucus, was also found in Europe and North America [80]. A single dipteran parasitoid, the tachinid Trichopoda pennipes (Fab.), was identified attacking nymphs and adults $[3,49,81]$. Tachinid eggs of several species have been found on adult $H$. halys, but these rarely develop to emergence as adult tachinids [82]. The microsporidian Nosema maddoxi has also been found in Europe in the Republic of Georgia [48], and also occurs in North America [83].

\section{Discussion}

Our study revealed that there are many predator and parasitoid species that can attack $H$. halys in both its native and invaded ranges. To reduce potential non-target impacts to native species, only the most efficient and highly specific natural enemies should be considered for use in classical biological control programs [84,85]. In Australia, Pentatomidae displays a high rate of endemism, with 330 species not found elsewhere [86]. Most natural enemies found in the native range of $H$. halys have low host specificity, and so there are very few options to control $H$. halys using natural enemies from its native range. All predators and pathogens found in the native range are generalists, and so they are unlikely to be considered for classical biological control programs. While they may be key elements in population regulation of $H$. halys in the native range, the risks associated with introducing any of these are too high for the Australian native fauna.

Most parasitoids of $H$. halys are egg parasitoids, and those found in the native and invaded ranges have varying levels of host specificity. Parasitoids with the widest host range should be excluded from any biological control program due to the risks associated with non-target effects. Similarly, preference should be given to parasitoids showing effective control of $H$. halys populations in their native range. Some $H$. halys egg parasitoids have not yet been identified to species [1,25], and so cannot yet be considered as potential biological control agents. While information on the genus can be used to make some inferences regarding $\mathrm{H}$. halys control, these are limited and not useful in the context of an Australian biological control program due to very strict requirements for considering new introductions, including clear taxonomic identification of potential biological control agents. The lack of clear taxonomic identification precludes Anastatus spp., Telenomus spp., as well as the potential hyperparasitoids Acroclisoides spp. and Ooencyrtus spp. from consideration in Australia. Furthermore, Anastatus spp. have a wide host range, sometimes across insect orders [87], and Telenomus spp. only attack H. halys sporadically, resulting in consistently low parasitization rates in China [16]. Therefore, it is unlikely that further work on these parasitoid species, including correct taxonomic identification, would be useful.

The egg parasitoid, T. japonicus, has been the focus of all biological control programs worldwide so far, including the United States [88], Italy [43,89], and New Zealand [90], because it has the highest parasitism rate (up to $80-85 \%$ ) compared to the other species (less than $10 \%)[16,40]$. The reason for this is unclear, but the evidence is consistent: T. japonicus is more effective than other egg parasitoids against $H$. halys $[1,16,40]$. In addition to the high parasitism rates in its native range, it also has a short generation time with several generations per year, high fecundity, and a sex ratio skewed toward females [40].

However, T. japonicus is known to parasitize and develop in eggs of other pentatomid species. In its native range, it has been recovered from seven species in the field [16]. In laboratory studies, it parasitized some, but not all pentatomid species tested [16,23,91,92]. In Japan, three non-target species are attacked, two of which are in the genus Plautia Stål $[39,93]$. A careful assessment of the potential risks to Australian Pentatomidae native fauna would need to be completed before T. japonicus could be considered as a possible biological control agent for $H$. halys there. 
Trissolcus japonicus was found to have already arrived in North America before host specificity tests were completed $[5,20,44,91,94,95]$. Trissolcus japonicus was also recently detected in Europe (Switzerland and Italy) [21,22,62]. Host specificity testing under laboratory conditions have shown that $T$. japonicus can parasitize several non-target species; however, some species were more susceptible than others, e.g., [82,91,96,97]. In choice tests, T. japonicus seemed to prefer eggs of $H$. halys [91]. A recent study showed that $T$. japonicus had a preference for H. halys, especially when it had been reared on H. halys eggs [97]. Interestingly, when reared on smaller non-target hosts, adults were smaller and produced fewer offspring, showing a fitness effect of using some alternate hosts for the parasitoid [97]. Another study showed that $T$. japonicus host searching was triggered by cues from $H$. halys, but not by the cues of another suitable host species, Podisus maculiventris (Say) [98]. This indicates that factors affecting host searching are also key in assessing potential non-host target issues in the field.

Host specificity testing of T. japonicus in New Zealand included eight species of pentatomids from the subfamilies Pentatominae and Asopinae [23]. New Zealand has only eight species of Pentatomidae, and two sub-species, of which five are native (one species and the two sub-species are endemic). Except for the three endemic New Zealand species, all these pentatomids are present in Australia and most also have congeneric species [23]. All species tested were attacked by T. japonicus in no-choice tests, except the green vegetable stinkbug, Nezara viridula, which is a pest in both countries [23,99]. Parasitism rates were highest for Cermatulus nasalis and Glaucias amyoti with 95\% parasitism, followed by Monteithiella humeralis (78\%) and Dictyotus caenosus (73\%) [23]. All four of these species are present in Australia. While T. japonicus was shown to parasitize non-target species, the decision to instigate preemptive biological control of $H$. halys was made due to the higher risks posed by $H$. halys relative to the comparatively low risks associated with T. japonicus on native species [24], which are found outside the potential distribution range of T. japonicus or in marginal areas $[23,90]$. For this reason, New Zealand recently conditionally pre-approved the release of $T$. japonicus, in the event of an introduction of $H$. halys [24], a world first action in preemptively deploying a management strategy against a potential future pest. On the other hand, Australia has a very diverse and highly endemic pentatomid fauna, and so it is unlikely that a parasitoid that can utilize several species within this family will be deemed suitable for introduction. Trissolcus japonicus has already been shown to parasitize some Australian pentatomid species in non-choice tests [23], although it appears to prefer $H$. halys [97] and may have minimal effect on other species under field conditions. Further studies, including testing Australian species in non-choice and choice tests, are necessary to assess the true non-target risks of this species.

Much less information is available for other Trissolcus spp., making it difficult to assess their potential as biological control agents. A key issue is that other Trissolcus spp. have lower parasitism rates compared to $T$. japonicus. It is unlikely that parasitoid species performing poorly in their native environments would perform substantially better and be able to control $H$. halys populations in a new environment. Low parasitism levels in the field may also indicate the preferential use of other hosts in the field. For example, parasitism levels of $H$. halys by T. plautiae varied (ranging from $<1$ to $20 \%$ ) depending on the habitat where it was found, and it seemed to prefer other hosts in the field [16]. Trissolcus cultratus was found parasitizing $H$. halys at low levels in the field in China, with only $8 \%$ of eggs being parasitized [16].

Host specificity is an issue for all Trissolcus species, as none are likely to be truly speciesspecific. Trissolcus species that have been reared from H. halys eggs (Table 1) have several hosts. Little is known about many of these Trissolcus species, including their biology, behavior, and ecology: they are inconspicuous and their taxonomy is challenging $[17,100]$. However, we can expect that further research would reveal broader host ranges, making them inherently risky as biological control agents. Broader host ranges coupled with low parasitism of $H$. halys eggs in their native ranges suggest that most species should not be considered further as potential biocontrol agents. However, Trissolcus mitsukurii is already 
present in Australia [101], and so while little is known of its distribution or ecology on the continent, its ability to parasitize warrants further examination.

Trissolcus mitsukurii is a known parasitoid of $H$. halys and other pentatomids in China and Japan [45], and is widespread through eastern and southeastern Asia [28,46]. The presence of T. mitsukurii in Australia was documented by Johnson (1991) [46], and recognized as a senior synonym of Telenomus oecleoides, a species described from Queensland in 1914. This work [46] provided a distribution map that illustrated a handful of localities of T. mitsukurii from the coastal areas of Queensland, Victoria, and South Australia. Trissolcus mitsukurii was more recently analyzed in a revision of Palearctic Trissolcus [28] and a molecular phylogeny of Trissolcus species associated with the brown marmorated stink bug [102]. In the updated context of this species, the holotype specimen of Telenomus oecleoides was reexamined and its morphological match to T. mitsukurii from Asia was confirmed. Additionally, two specimens of T. mitsukurii from Queensland were documented from the Australian National Insect Collection (Figure 1).

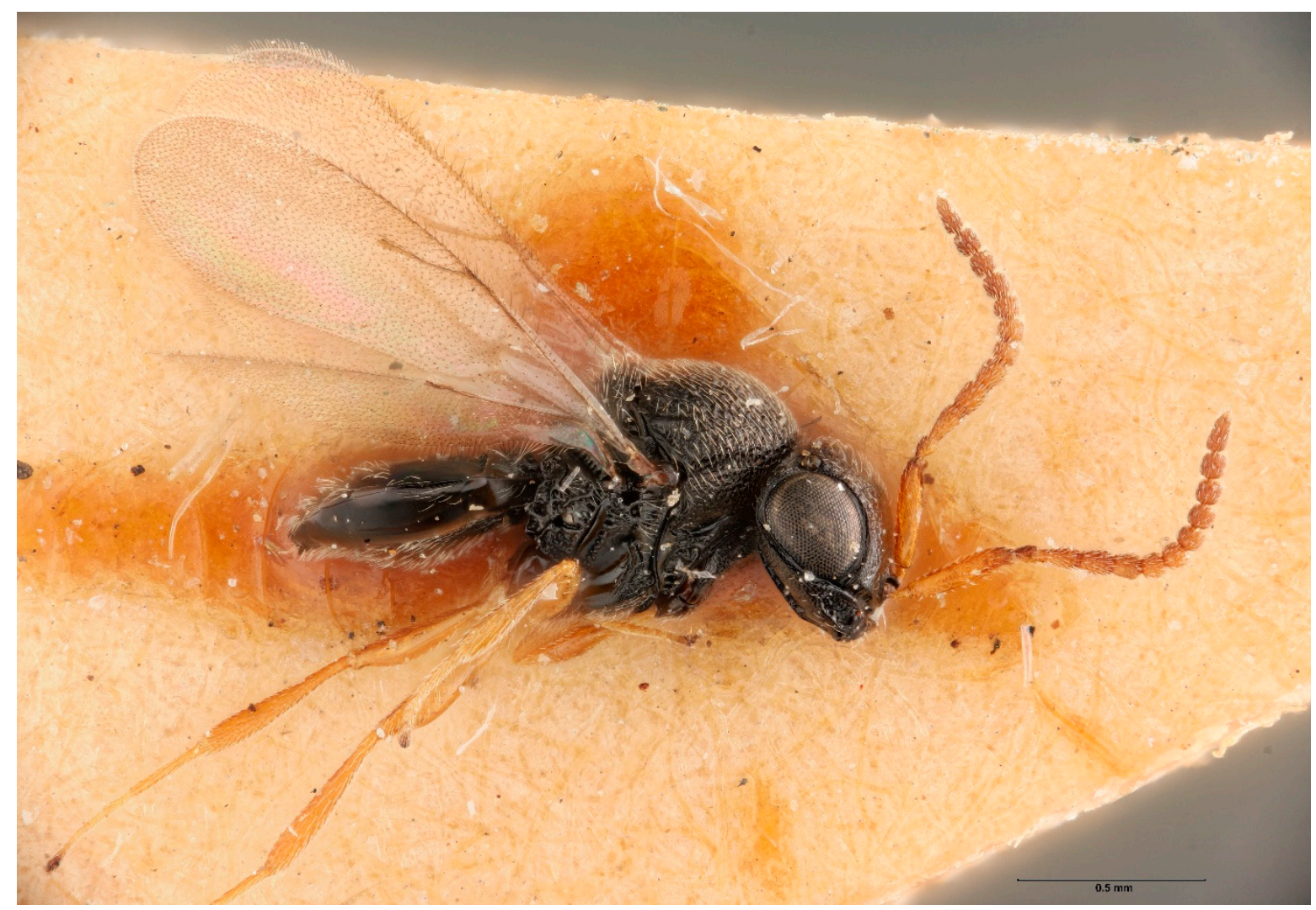

Figure 1. Trissolcus mitsukurii male (ANIC32-020631), collected in Brisbane, 1936.

Very little information is available on T. mitsukurii as a biological control agent, despite having been "introduced" into Australia in the 1960s [101] when it was released in every state and the Australian Capital Territory. It was subsequently recovered in the field in 1964 in ACT, South Australia, and NSW [101]. Specimens have also been collected from Queensland, Victoria, and New South Wales between 1967 and 1987 and can be found preserved in insect collections in Australia and overseas [103]. Following the invasion of H. halys into Europe, T. mitsukurii recently invaded Italy, where it was detected for the first time in 2016 [62], and has since continued to spread in Northern Italy [21,62,76].

There is little information available on the biology and ecology of T. mitsukurii. However, its recent introduction in Italy has provided the opportunity to improve knowledge of this species $[62,89]$. An early Asian study looking at its development rate in the laboratory under different temperatures showed that development could be completed at $17.5^{\circ} \mathrm{C}$ 
and above [30], with males developing faster than females. At $21^{\circ} \mathrm{C}$, males took between 10-13 days to develop, while females took 11-15 days [89]. The temperature threshold for this species was estimated to be $11.7^{\circ} \mathrm{C}$ for males and $11.8^{\circ} \mathrm{C}$ for females, with 191.2 degree days above this temperature needed to complete development. Based on this data, as many as 14-15 generations per year could occur [30]. Trissolcus mitsukurii was introduced into Brazil [71], but it is not clear whether it has been permanently established there, as there are no location records to indicate that it is present [13]. Nonetheless, experiments in Brazil indicated that longevity depends on rearing temperatures [104], and that T. mitsukurii could live for 42.6 days at $26^{\circ} \mathrm{C}$ [105]. Whist one study indicated that lifespan increased when food was provided [89], another study found the opposite [104]. On average, females can lay 80.3 eggs in their lifetime at $26^{\circ} \mathrm{C}$ [105]. A more recent study indicated that the mean progeny per female ranged between 63 and 83, sex ratio of offspring was always female-biased, and female propensity to lay eggs decreased with number of days that host eggs were offered [89]. Interestingly, when not provided with hosts, females accumulated eggs in their ovaries, and laid these rapidly once hosts were available again [89].

The host range of T. mitsukurii (Table 2) includes several species of Pentatomidae, Dinidoridae and one Lepidoptera, although the two latter should be confirmed. In Japan, T. mitsukurii was reported from seven species of pentatomids. Adults of T. mitsukurii were larger, lived longer, and had higher fecundity when reared on $H$. halys eggs than when emerging from N. viridula and Plautia crossata stali [45]. In Brazil, it was shown to parasitize eggs of all five major pentatomids of soybeans under laboratory conditions [104].

Table 2. Host range of Trissolcus mitsukurii including taxonomy of the host, country of occurrence, if present in Australia.

\begin{tabular}{|c|c|c|c|c|c|c|c|}
\hline Order & Family & Tribe & Name & Country & $\begin{array}{l}\text { Present in } \\
\text { Australia }\end{array}$ & $\begin{array}{l}\text { Congenerics in } \\
\text { Australia }\end{array}$ & References \\
\hline \multirow[t]{17}{*}{ Hemiptera } & \multirow[t]{16}{*}{ Pentatomidae } & Carpocorini & $\begin{array}{l}\text { Dolycoris } \\
\text { baccarum }\end{array}$ & Japan & No & No & {$[19,39,93]$} \\
\hline & & Carpocorini & Euschistus sp. & Brazil & No & No & {$[104]$} \\
\hline & & \multirow{3}{*}{ Phyllocephalini } & $\begin{array}{l}\text { Palomena } \\
\text { prasina }\end{array}$ & Italy & No & No & [19] \\
\hline & & & Gonopsis affinis & Japan & No & No & [93] \\
\hline & & & $\begin{array}{l}\text { Lagynotomus } \\
\text { assimulans }\end{array}$ & Japan & No & No & [93] \\
\hline & & Edessini & Edessa sp. & Brazil & No & No & [104] \\
\hline & & Nezarini & $\begin{array}{l}\text { Nezara } \\
\text { antennata }\end{array}$ & Japan & No & $1 \mathrm{sp}$. in genus & [93] \\
\hline & & Nezarini & Nezara viridula & Japan & Yes (exotic) & No & {$[19,45,46]$} \\
\hline & & Nezarini & Nezara sp. & Brazil & No & No & {$[104]$} \\
\hline & & Piezodorini & $\begin{array}{l}\text { Piezodorus } \\
\text { hybneri }\end{array}$ & Japan & No & $1 \mathrm{sp}$. in genus & {$[39,93]$} \\
\hline & & Pentatomini & Acrosternum sp. & Brazil & No & No & [104] \\
\hline & & Piezodorini & Piezodorus sp. & Brazil & - & $1 \mathrm{sp}$. in genus & [104] \\
\hline & & Antestini & $\begin{array}{c}\text { Plautia crossota } \\
\text { stali }\end{array}$ & Japan & No & 3 spp. in genus & {$[45]$} \\
\hline & & Rhynchocorini & Biprorulus bibax & Australia & Yes & No & {$[46,106]$} \\
\hline & & Rhynchocorini & $\begin{array}{l}\text { Cuspicona } \\
\text { privata }\end{array}$ & Australia & Yes & 18 spp. in genus & [46] \\
\hline & & Halyini & Poecilometis sp. & Unknown & Yes & $\begin{array}{c}31 \text { spp. and } 11 \\
\text { subspp. in genus }\end{array}$ & [46] \\
\hline & Dinidoridae & Megymenini & $\begin{array}{l}\text { Megymenum } \\
\text { gracilicorne }\end{array}$ & Unknown & No & 1 spp. in genus & [39] \\
\hline Lepidoptera & Lasiocampidae & & Trabala vishnou & Unknown & No & No & [46] \\
\hline
\end{tabular}

Trissolcus mitsukurii was found parasitizing two non-target species in Australia: Cuspicona privata Walker and the spined citrus bug Biprorulus bibax Breddin $[46,106]$. Poecilometis sp. was reported as a laboratory host, with no further information provided [46]. Poecilometis is a very diverse genus with $31 \mathrm{spp}$. and 11 subspecies in Australia. Trissolcus mitsukurii was also associated with a Lepidopteran, Trabala vishnou Lefèbvre (Lasiocampidae) [46]. However, as this is the only record of a Lepidoptera attacked by T. mitsukurii and the genus Trissolcus is known to only use Hemiptera as hosts [46], caution should be 
used with this record. A recent study [19] found that T. mitsukurii rarely parasitized native Italian stinkbug species.

Little is known about parasitism rates of T. mitsukurii in its native range, as very few studies have provided information for this species in the field. However, T. mitsukurii is considered one of the main egg parasitoids of H. halys in Japan [45]. In Italy, T. mitsukurii was the most abundant parasitoid collected from $H$. halys egg masses between 2016-2018 [62]. However, more recent studies $[19,76]$ showed that the level of parasitism of T. mitsukurii depended on the site. Trissolcus mitsukurii also had the highest parasitism rate (7.7-15.1\% of eggs parasitized) and exploitation efficiency (i.e., the number of eggs parasitized per egg mass), compared to other egg parasitoids [62], although this was not the case in later studies [19]. In Brazil, in a field experiment where 1000 T. mitsukurii females were released, $50 \%$ of $N$. viridula and three other pentatomids of soybeans were parasitized at the release site. Two weeks after release, parasitism was found $100 \mathrm{~m}$ away from the site, and T. mitsukurii was the dominant species, showing competitive behavior over other egg parasitoids [104].

As T. mitsukurii is already in Australia, it is adapted to Australian conditions and would already be available to attack $H$. halys if this pest is introduced. To predict the efficiency of this species in Australia, studies with $H$. halys should be conducted. A biological program with T. mitsukurii would involve augmentative releases of the parasitoid to control $H$. halys and potential redistribution into new areas where it has not yet been found. Its recent introduction in Italy and experimental work done in Brazil on N. viridula [104] indicate that T. mitsukurii could contribute in controlling $H$. halys populations if it becomes established in Australia.

\section{Conclusions}

In summary, our review shows that only two species could be considered as classical biological control agents against H. halys in Australia: T. japonicus and T. mitsukurii. Extensive surveys in China, Korea, and Japan from 2007 through 2018 have not revealed any novel egg parasitoids beyond those listed in Table 1 [82]. Whilst additional surveys in the native range of $H$. halys may yield more natural enemies, it is unlikely that these would be more efficient or more host-specific than T. japonicus. Trissolcus japonicus is the top candidate for other countries due to its high efficiency and relatively narrow host range (oligophagous within stink bugs); however, because Australia has a highly diverse stink bug fauna, more information on its potential impact on native species is needed before it can be considered.

As discussed, T. japonicus is unlikely to be purposefully introduced into Australia because its relatively broad host range makes it unacceptable to Australian biosecurity regulators. However, T. mitsukurii is already present in Australia and available in the event of an incursion of $H$. halys. Unfortunately, because relatively little is known about $T$. mitsukurii, research is required to assess its potential as an effective biological control agent.

Therefore, as a priority, future work on T. mitsukurii and biological control of H. halys in Australia should include:

(1) Confirming the Australian distribution of T. mitsukurii. Using Nezara viridula eggs as sentinels will determine the distribution and abundance of T. mitsukurii. Locality records of T. mitsukurii are available from the first half of the 20th century and after populations were introduced from Asia in the 1960s, when it was recovered in several states and recorded in the Atlas of Living Australia (2018). However, no further information is available to confirm its current distribution. This information is paramount in the event of an introduction of $H$. halys, as T. mitsukurii may need to be introduced to new areas.

(2) Determining the ecology of T. mitsukurii in the field, e.g., [45,62,107]. Using an alternative host such as Nezara viridula to survey for T. mitsukurii will also provide useful information about its ecology and microhabitat preferences. Understanding the behavior and biology of T. mitsukurii prior to the arrival of $H$. halys will be important to quantify 
any changes in host preference and efficiency as a biological control when both hosts are available.

(3) Establishing the host range of T. mitsukurii. Very little is known of the host range of T. mitsukurii and its use of native Australian Pentatomidae species as alternative hosts. It is possible that T. mitsukurii has had non-target effects, but if so, these are unknown. The host range should therefore be assessed before T. mitsukurii is actively introduced into new areas.

(4) Assessing the potential role of native predator and parasitoid species as additional biocontrol agents. Because Australia has a high diversity of species in Pentatomidae, we would expect a high diversity of parasitoids and other natural enemies presently utilizing this group. Because these native parasitoids and predators may be able to also parasitize $H$. halys and offer some control, it is essential that we survey and catalogue these species and assess their potential to control the invasive $H$. halys.

Author Contributions: Conceptualization, V.C., K.A.H., and G.A.A.; methodology, V.C.; writingoriginal draft preparation, V.C., T.Y., C.P., and K.A.H.; writing-review and editing, K.A.H., G.A.A., C.P., T.Y., and E.J.T. funding acquisition, V.C. All authors have read and agreed to the published version of the manuscript.

Funding: This research was funded by the Australian Department of Agriculture and Water and the Environment.

Institutional Review Board Statement: Not applicable.

Informed Consent Statement: Not applicable.

Data Availability Statement: Not applicable.

Acknowledgments: We thank Saleta Perez Vila, and Patrick Gleeson for reviewing this manuscript and Andy Sheppard for useful discussions.

Conflicts of Interest: The authors declare no conflict of interest.

\section{References}

1. Lee, D.H.; Short, B.D.; Joseph, S.V.; Bergh, J.C.; Leskey, T.C. Review of the biology, ecology, and management of Halyomorpha halys (Hemiptera: Pentatomidae) in China, Japan, and the Republic of Korea. Environ. Entomol. 2013, 42, 627-641. [CrossRef] [PubMed]

2. Yu, G.; Zhang, J. The brown marmorated stink bug, Halyomorpha halys (Heteroptera: Pentatomidae) in PR China. In Proceedings of the International Workshop on Biological Control of Invasive Species of Forests, Beijing, China, 20-25 September 2007; pp. 58-62.

3. Rice, K.B.; Bergh, C.J.; Bergmann, E.J.; Biddinger, D.J.; Dieckhoff, C.; Dively, G.; Fraser, H.; Gariepy, T.; Hamilton, G.; Haye, T.; et al. Biology, ecology, and management of brown marmorated stink bug (Hemiptera: Pentatomidae). J. Integr. Pest Manag. 2014, 5, A1-A13. [CrossRef]

4. Gariepy, T.D.; Fraser, H.; Scott-Dupree, C.D. Brown marmorated stink bug (Hemiptera: Pentatomidae) in Canada: Recent establishment, occurrence, and pest status in southern Ontario. Can. Entomol. 2014, 146, 579-582. [CrossRef]

5. Leskey, T.C.; Nielsen, A.L. Impact of the invasive brown marmorated stink bug in North America and Europe: History, biology, ecology, and management. Annu. Rev. Entomol. 2018, 63, 599-618. [CrossRef] [PubMed]

6. Faúndez, E.I.; Rider, D.A. The brown marmorated stink bug Halyomorpha halys (Stål, 1855) (Het.: Pentatomidae) in Chile. Arq. Entomolóxicos 2017, 17, 305-307.

7. Inkley, D.B. Characteristics of home invasion by the brown marmorated stink bug (Hemiptera: Pentatomidae). J. Entomol. Sci. 2012, 47, 125-130. [CrossRef]

8. Kriticos, D.J.; Kean, J.M.; Phillips, C.B.; Senay, S.D.; Acosta, H.; Haye, T. The potential global distribution of the brown marmorated stink bug, Halyomorpha halys, a critical threat to plant biosecurity. J. Pest Sci. 2017, 90, 1033-1043. [CrossRef]

9. Horwood, M.; Milnes, J.M.; Cooper, W.R. Brown marmorated stink bug, Halyomorpha halys (Hemiptera: Pentatomidae), detections in Western Sydney, New South Wales, Australia. Austral. Entomol. 2019, 58, 857-865. [CrossRef]

10. BNZ. Brown Marmorated Stink Bug Requirements. Available online: https://www.mpi.govt.nz/import/vehicles-machineryparts / requirement-documents-for-importing-vehicles-machinery-or-parts/brown-marmorated-stink-bug-requirements-forimporters / (accessed on 20 May 2021).

11. DAWR. Final Pest Risk Analysis for Brown Marmorated Stink Bug (Halyomorpha halys). 2019. Available online: https://www. agriculture.gov.au/sites/default/files/documents / final-bmsb-pra-report.pdf (accessed on 20 May 2021).

12. HIA. Australian Horticulture Statistics Handbook-Vegetables 2014/2015; Horticulture Innovation Australia: Sydney, Australia, 2016. 
13. Yonow, T.; Kriticos, D.J.; Ota, N.; Avila, G.A.; Talamas, E.J.; Hoelmer, K.A.; Chen, H.Y.; Caron, V. Modelling the potential geographic distribution of two Trissolcus species for the brown marmorated stink bug, Halyomorpha halys. Insects 2021, 12, 491. [CrossRef]

14. Nielsen, A.L.; Shearer, P.W.; Hamilton, G.C. Toxicity of insecticides to Halyomorpha halys (Hemiptera: Pentatomidae) using glass-vial bioassays. J. Econ. Entomol. 2008, 101, 1439-1442. [CrossRef]

15. Leskey, T.C.; Short, B.D.; Lee, D.H. Efficacy of insecticide residues on adult Halyomorpha halys (Stal) (Hemiptera: Pentatomidae) mortality and injury in apple and peach orchards. Pest Manag. Sci. 2014, 70, 1097-1104. [CrossRef]

16. Zhang, J.P.; Zhang, F.; Gariepy, T.; Mason, P.; Gillespie, D.; Talamas, E.; Haye, T. Seasonal parasitism and host specificity of Trissolcus japonicus in northern China. J. Pest Sci. 2017, 90, 1127-1141. [CrossRef]

17. Talamas, E.J.; Buffington, M.; Hoelmer, K. New synonymy of Trissolcus halyomorphae Yang. J. Hymenopt. Res. 2013, 33, 113-117. [CrossRef]

18. Haye, T.; Fischer, S.; Zhang, J.; Gariepy, T. Can native egg parasitoids adopt the invasive brown marmorated stink bug, Halyomorpha halys (Heteroptera: Pentatomidae), in Europe? J. Pest Sci. 2015, 88, 693-705. [CrossRef]

19. Zapponi, L.; Tortorici, F.; Anfora, G.; Bardella, S.; Bariselli, M.; Benvenuto, L.; Bernardinelli, I.; Butturini, A.; Caruso, S.; Colla, R.; et al. Assessing the distribution of exotic egg parasitoids of Halyomorpha halys in Europe with a large-scale monitoring program. Insects 2021, 12, 316. [CrossRef]

20. Talamas, E.J.; Herlihy, M.V.; Dieckhoff, C.; Hoelmer, K.A.; Buffington, M.L.; Bon, M.C.; Weber, D.C. Trissolcus japonicus (Ashmead) (Hymenoptera, Scelionidae) emerges in North America. J. Hymenopt. Res. 2015, 43, 119-128. [CrossRef]

21. Sabbatini Peverieri, G.; Talamas, E.; Bon, M.C.; Marianelli, L.; Bernardinelli, I.; Malossini, G.; Benvenuto, L.; Roversi, P.F.; Hoelmer K. Two Asian egg parasitoids of Halyomorpha halys (Stal) (Hemiptera, Pentatomidae) emerge in northern Italy: Trissolcus mitsukurii (Ashmead) and Trissolcus japonicus (Ashmead) (Hymenoptera, Scelionidae). J. Hymenopt. Res. 2018, 67, 37-53. [CrossRef]

22. Stahl, J.M.; Tortorici, F.; Pontini, M.; Bon, M.C.; Hoelmer, K.; Marazzi, C.; Tavella, L.; Haye, T. First discovery of adventive populations of Trissolcus japonicus in Europe. J. Pest Sci. 2018. [CrossRef]

23. Charles, J.G.; Avila, G.A.; Hoelmer, K.A.; Hunt, S.; Gardner-Gee, R.; MacDonald, F.; Davis, V. Experimental assessment of the biosafety of Trissolcus japonicus in New Zealand, prior to the anticipated arrival of the invasive pest Halyomorpha halys. BioControl 2019, 64, 367-379. [CrossRef]

24. EPA. Application to Seek Pre-Approval to Release Trissolcus japonicus (the Samurai Wasp) as a Biological Control Agent for Brown Marmorated Stink Bug (Halyomorpha halys) Should it Arrive in New Zealand; Decision. Available online: https: / / www.epa.govt.nz/assets/FileAPI/hsno-ar/APP203336/0ed5350647/APP203336-Decision.pdf (accessed on 5 May 2021).

25. Kawada, H.; Kitamura, C. The tachinid fly, Bogosia sp. (Diptera: Tachinidae) as a parasitoid of the brown marmorated stink bug, Halyomorpha mista Uhler (Heteroptera: Pentatomidae). Jpn. J. Appl. Environ. Entomol. Zool. 1992, 4, 65-70.

26. Qiu, L.; Yang, Z.; Tao, W.; Qiu, L.F.; Yang, Z.Q.; Tao, W.Q. Biology and population dynamics of Trissolcus halyomorphae. Sci. Silvae Sin. 2007, 43, 62-65.

27. Kamiyama, M.T.; Matsuura, K.; Yoshimura, T.; Yang, C.C.S. Predation of the brown marmorated stink bug, Halyomorpha halys by the Japanese acrobat ants, Crematogaster matsumurai and Crematogaster osakensis. Biol. Control 2021, 157. [CrossRef]

28. Talamas, E.J.; Buffington, M.L.; Hoelmer, K. Revision of Palearctic Trissolcus Ashmead (Hymenoptera, Scelionidae). J. Hymenopt. Res. 2017, 56, 3-185. [CrossRef]

29. Tortorici, F.; Talamas, E.J.; Moraglio, S.T.; Pansa, M.G.; Asadi-Farfar, M.; Tavella, L.; Caleca, V. A morphological, biological and molecular approach reveals four cryptic species of Trissolcus Ashmead (Hymenoptera, Scelionidae), egg parasitoids of Pentatomidae (Hemiptera). J. Hymenopt. Res. 2019, 73, 153-200. [CrossRef]

30. Arakawa, R.; Namura, Y. Effects of temperature on development of three Trissolcus spp. (Hymenoptera: Scelionidae), egg parasitoids of the brown marmorated stink bug, Halyomorpha halys (Hemiptera: Pentatomidae). Entomol. Sci. 2002, 5, $215-218$.

31. Clarke, A.R.; Seymour, J.E. Two species of Acroclisoides Girault and Dodd (Hymenoptera: Pteromalidae) parasitic on Trissolcus basalis (Wollaston) (Hymenoptera: Scelionidae), a parasitoid of Nezara viridula (L.) (Hemiptera: Pentatomidae). Aust. J. Entomol. 1992, 31, 299-300. [CrossRef]

32. Triapitsyn, S.V.; Andreason, S.A.; Power, N.; Ganjisaffar, F.; Fusu, L.; Dominguez, C.; Perring, T.M. Two new species of Ooencyrtus (Hymenoptera, Encyrtidae), egg parasitoids of the bagrada bug Bagrada hilaris (Hemiptera, Pentatomidae), with taxonomic notes on Ooencyrtus telenomicida. J. Hymenopt. Res. 2020, 76, 57-98. [CrossRef]

33. Giovannini, L.; Sabbatini-Peverieri, G.; Tillman, P.G.; Hoelmer, K.A.; Roversi, P.F. Reproductive and developmental biology of Acroclisoides sinicus, a hyperparasitoid of scelionid parasitoids. Biology 2021, 10, 229. [CrossRef]

34. Stahl, J.M.; Babendreier, D.; Foti, M.C.; Colazza, S.; Haye, T. Intrinsic competition between two European egg parasitoids of the brown marmorated stink bug. J. Appl. Entomol. 2020, 144, 669-677. [CrossRef]

35. Chen, J.; Li, W.; Mi, Q.; Zhang, F.; Shi, S.; Zhang, J. A newly reported parasitoid, Pentatomophaga latifascia (Diptera: Tachinidae), of adult Halyomorpha halys in Beijing, China. Insects 2020, 11, 666. [CrossRef]

36. Nakashima, N.; Sasaki, J.; Tsuda, K.; Yasunaga, C.; Noda, H. Properties of a new picorna-like virus of the brown-winged green bug, Plautia stali. J. Invertebr. Pathol. 1998, 71, 151-158. [CrossRef]

37. Hajek, A.E.; Solter, L.F.; Maddox, J.V.; Huang, W.F.; Estep, A.S.; Krawczyk, G.; Weber, D.C.; Hoelmer, K.A.; Sanscrainte, N.D.; Becnel, J.J. Nosema maddoxi sp nov (Microsporidia, Nosematidae), a widespread pathogen of the Green Stink Bug Chinavia hilaris (Say) and the Brown Marmorated Stink Bug Halyomorpha halys (Stal). J. Eukaryot. Microbiol. 2018, 65, 315-330. [CrossRef] 
38. Sasaki, F.; Miyamoto, T.; Yamamoto, A.; Tamai, Y.; Yajima, T. Relationship between intraspecific variations and host insects of Ophiocordyceps nutans collected in Japan. Mycoscience 2012, 53, 85-91. [CrossRef]

39. Rider, D.A. Hymenoptera Parasitoid Records_List by Parasitoid Species. Available online: https://www.ndsu.edu/faculty/ rider/Pentatomoidea/Natural_Enemies/parasitoid_Hymen_Host.htm (accessed on 24 November 2018).

40. Yang, Z.Q.; Yao, Y.X.; Qiu, L.F.; Li, Z.X. A new species of Trissolcus (Hymenoptera: Scelionidae) parasitizing eggs of Halyomorpha halys (Heteroptera: Pentatomidae) in China with comments on its biology. Ann. Entomol. Soc. Am. 2009, 102, 39-47. [CrossRef]

41. Kim, K.; Choi, D.; Choi, J.; Hong, K.; Kim, K.Y.; Choi, D.S.; Choi, J.Y.; Hong, K.J. Host records of Trissolcus (Hymenoptera: Platygasteridae: Telenominae) parasitizing eggs of stink bugs in Korea. Korean J. Appl. Entomol. 2017, 56, 87-92. [CrossRef]

42. Matsuo, K.; Honda, T.; Itoyama, K.; Toyama, M.; Hirose, Y. Discovery of three egg parasitoid species attacking the shield bug Glaucias subpunctatus (Hemiptera: Pentatomidae). Jpn. J. Appl. Entomol. Zool. 2016, 60, 43-45. [CrossRef]

43. Sabbatini-Peverieri, G.; Boncompagni, L.; Mazza, G.; Paoli, F.; Dapporto, L.; Giovannini, L.; Marianelli, L.; Hoelmer, K.; Roversi, P.F. Combining physiological host range, behavior and host characteristics for predictive risk analysis of Trissolcus japonicus. J. Pest Sci. 2021. [CrossRef]

44. Abram, P.K.; Talamas, E.J.; Acheamponge, S.; Mason, P.G.; Gariepy, T.D. First detection of the samurai wasp, Trissolcus japonicus (Ashmead) (Hymenoptera, Scelionidae), in Canada. J. Hymenopt. Res. 2019, 68, 29-36. [CrossRef]

45. Arakawa, R.; Miura, M.; Fujita, M. Effects of host species on the body size, fecundity, and longevity of Trissolcus mitsukurii (Hymenoptera: Scelionidae), a solitary egg parasitoid of stink bugs. Appl. Entomol. Zool. 2004, 39, 177-181. [CrossRef]

46. Johnson, N.F. Revision of Australasian Trissolcus species (Hymenoptera: Scelionidae) Invertebr. Taxon. 1991, 5, 211-239. [CrossRef]

47. Lim, U.; Park, K.; Mahmoud, A.M.A.; Jung, C.; Lim, U.T.; Park, K.S.; Jung, C.E. Areal distribution and parasitism on other soybean bugs of Trissolcus nigripedius (Hymenoptera: Scelionidae), an egg parasitoid of Dolycoris baccarum (Heteroptera: Pentatomidae). Korean J. Appl. Entomol. 2007, 46, 79-85. [CrossRef]

48. Kereselidze, M.; Pilarska, D.; Linde, A.; Sanscrainte, N.D.; Hajek, A.E. Nosema maddoxi infecting the brown marmorated stink bug, Halyomorpha halys (Stal) (Hemiptera: Pentatomidae), in the Republic of Georgia. Biocontrol Sci. Techn. 2020, 30, 1083-1089. [CrossRef]

49. Abram, P.K.; Hoelmer, K.A.; Acebes-Doria, A.; Andrews, H.; Beers, E.H.; Bergh, J.C.; Bessin, R.; Biddinger, D.; Botch, P.; Buffington, M.L.; et al. Indigenous arthropod natural enemies of the invasive brown marmorated stink bug in North America and Europe. J. Pest Sci. 2017, 90, 1009-1020. [CrossRef]

50. Pote, J.M.; Nielsen, A.L. Life stage specific predation of Halyomorpha halys (St(a)over-circlel) by generalist predators. Biol. Control 2017, 114, 1-7. [CrossRef]

51. Abram, P.K.; Doyon, J.; Brodeur, J.; Gariepy, T.D.; Boivin, G. Susceptibility of Halyomorpha halys (Hemiptera: Pentatomidae) eggs to different life stages of three generalist predators. Can. Entomol. 2015, 147, 222-226. [CrossRef]

52. Arellano, R.; Medal, J.; Arellano, G.; Perez, J. Feeding responses of Euthyrhinchus floridanus (Hemiptera: Pentatomidae) to brown marmorated stinkbug (Hemiptera: Pentatomidae) adults and nymphs. Fla. Entomol. 2019, 102, 658-659. [CrossRef]

53. Poley, K.; Bahlai, C.; Grieshop, M. Functional response of generalist predators to Halyomorpha halys (Hemiptera: Pentatomidae) eggs. Environ. Entomol. 2018, 47, 1117-1127. [CrossRef] [PubMed]

54. Morrison, W.R.; Mathews, C.R.; Leskey, T.C. Frequency, efficiency, and physical characteristics of predation by generalist predators of brown marmorated stink bug (Hemiptera: Pentatomidae) eggs. Biol. Control 2016, 97, 120-130. [CrossRef]

55. Lowenstein, D.M.; Andrews, H.; Rudolph, E.; Sullivan, E.; Marshall, C.J.; Wiman, N.G. Astata unicolor (Hymenoptera: Crabronidae) Population in Oregon with Observation of Predatory Behavior on Pentatomidae. Ann. Entomol. Soc. Am. 2018, 111, 122-126. [CrossRef]

56. Biddinger, D.J.; Joshi, N.K. First report of native Astata unicolor (Hymenoptera: Crabronidae) predation on the nymphs and adults of the invasive brown marmorated stink bug (Hemiptera: Pentatomidae). Fla. Entomol. 2017, 100, 809-812. [CrossRef]

57. Biddinger, D.J.; Surcica, A.; Joshi, N.K. A native predator utilising the invasive brown marmorated stink bug, Halyomorpha halys (Hemiptera: Pentatomidae) as a food source. Biocontrol Sci. Technol. 2017, 27, 903-907. [CrossRef]

58. Morrison, W.R.; Bryant, A.N.; Poling, B.; Quinn, N.F.; Leskey, T.C. Predation of Halyomorpha halys (Hemiptera: Pentatomidae) from web-building spiders associated with anthropogenic dwellings. J. Insect Behav. 2017, 30, 70-85. [CrossRef]

59. Bulgarini, G.; Badra, Z.; Leonardi, S.; Maistrello, L. Predatory ability of generalist predators on eggs, young nymphs and adults of the invasive Halyomorpha halys in southern Europe. Biocontrol 2020. [CrossRef]

60. Castracani, C.; Bulgarini, G.; Giannetti, D.; Spotti, F.A.; Maistrello, L.; Mori, A.; Grasso, D.A. Predatory ability of the ant Crematogaster scutellaris on the brown marmorated stink bug Halyomorpha halys. J. Pest Sci. 2017, 90, 1181-1190. [CrossRef]

61. Ogburn, E.C.; Bessin, R.; Dieckhoff, C.; Dobson, R.; Grieshop, M.; Hoelmer, K.A.; Mathews, C.; Moore, J.; Nielsen, A.L.; Poley, K.; et al. Natural enemy impact on eggs of the invasive brown marmorated stink bug, Halyomorpha halys (Stal) (Hemiptera: Pentatomidae), in organic agroecosystems: A regional assessment. Biol. Control 2016, 101, 39-51. [CrossRef]

62. Scaccini, D.; Falagiarda, M.; Tortorici, F.; Martinez-Sañudo, I.; Tirello, P.; Reyes-Domínguez, Y.; Gallmetzer, A.; Tavella, L.; Zandigiacomo, P.; Duso, C.; et al. An insight into the role of Trissolcus mitsukurii as biological control agent of Halyomorpha halys in Northeastern Italy. Insects 2020, 11, 306. [CrossRef] [PubMed]

63. Tillman, G.; Toews, M.; Blaauw, B.; Sial, A.; Cottrell, T.; Talamas, E.; Buntin, D.; Joseph, S.; Balusu, R.; Fadamiro, H.; et al. Parasitism and predation of sentinel eggs of the invasive brown marmorated stink bug, Halyomorpha halys (Stål) (Hemiptera: Pentatomidae), in the southeastern US. Biol. Control 2020, 145, 104247. [CrossRef] 
64. Ogburn, E.C.; Walgenbach, J.F. Effects of insecticides used in organic Agriculture on Anastatus reduvii (Hymenoptera: Eupelmidae) and Telenomus podisi (Hymenoptera: Scelionidae), egg parasitoids of pestivorous stink bugs. J. Econ. Entomol. 2019, 112, 108-114. [CrossRef] [PubMed]

65. Balusu, R.R.; Cottrell, T.E.; Talamas, E.J.; Toews, M.D.; Blaauw, B.R.; Sial, A.A.; Buntin, D.G.; Vinson, E.L.; Fadamiro, H.Y.; Tillman, G.P. New record of Trissolcus solocis (Hymenoptera: Scelionidae) parasitising Halyomorpha halys (Hemiptera: Pentatomidae) in the United States of America. Biodivers. Data J. 2019, 7. [CrossRef]

66. Balusu, R.R.; Talamas, E.J.; Cottrell, T.E.; Toews, M.D.; Blaauw, B.R.; Sial, A.A.; Buntin, D.G.; Fadamiro, H.Y.; Tillman, G. First record of Trissolcus basalis (Hymenoptera: Scelionidae) parasitizing Halyomorpha halys (Hemiptera: Pentatomidae) in the United States. Biodivers. Data J. 2019, 7. [CrossRef]

67. Cornelius, M.L.; Dieckhoff, C.; Hoelmer, K.A.; Olsen, R.T.; Weber, D.C.; Herlihy, M.V.; Talamas, E.J.; Vinyard, B.T.; Greenstone, M.H. Biological control of sentinel egg masses of the exotic invasive stink bug Halyomorpha halys (Stal) in Mid-Atlantic USA ornamental landscapes. Biol. Control 2016, 103, 11-20. [CrossRef]

68. Cornelius, M.L.; Dieckhoff, C.; Vinyard, B.T.; Hoelmer, K.A. Parasitism and predation on sentinel egg masses of the brown marmorated stink bug (Hemiptera: Pentatomidae) in three vegetable crops: Importance of dissections for evaluating the impact of native parasitoids on an exotic pest. Environ. Entomol. 2016, 45, 1536-1542. [CrossRef] [PubMed]

69. Costi, E.; Haye, T.; Maistrello, L. Surveying native egg parasitoids and predators of the invasive Halyomorpha halys in Northern Italy. J. Appl. Entomol. 2019, 143, 299-307. [CrossRef]

70. Dieckhoff, C.; Tatman, K.M.; Hoelmer, K.A. Natural biological control of Halyomorpha halys by native egg parasitoids: A multi-year survey in northern Delaware. J. Pest Sci. 2017, 90, 1143-1158. [CrossRef]

71. Gariepy, T.D.; Bruin, A.; Konopka, J.; Scott-Dupree, C.; Fraser, H.; Bon, M.C.; Talamas, E. A modified DNA barcode approach to define trophic interactions between native and exotic pentatomids and their parasitoids. Mol. Ecol. 2019, 28, 456-470. [CrossRef] [PubMed]

72. Herlihy, M.V.; Talamas, E.J.; Weber, D.C. Attack and success of native and exotic parasitoids on eggs of Halyomorpha halys in three Maryland habitats. PLOS ONE 2016, 11. [CrossRef]

73. Zapponi, L.; Bon, M.C.; Fouani, J.M.; Anfora, G.; Schmidt, S.; Falagiarda, M. Assemblage of the egg parasitoids of the invasive stink bug Halyomorpha halys: Insights on plant host associations. Insects 2020, 11, 588. [CrossRef] [PubMed]

74. Pezzini, D.T.; Santacruz, E.C.N.; Koch, R.L. Predation and parasitism of Halyomorpha halys (Hemiptera: Pentatomidae) eggs in Minnesota. Environ. Entomol. 2018, 47, 812-821. [CrossRef]

75. Peterson, H.M.; Talamas, E.; Krawczyk, G. Survey for adventive populations of the samurai wasp, Trissolcus japonicus (Hymenoptera: Scelionidae) in Pennsylvania at commercial fruit orchards and the surrounding forest. Insects 2021, 12, 258. [CrossRef]

76. Moraglio, S.T.; Tortorici, F.; Pansa, M.G.; Castelli, G.; Pontini, M.; Scovero, S.; Visentin, S.; Tavella, L. A 3-year survey on parasitism of Halyomorpha halys by egg parasitoids in northern Italy. J. Pest Sci. 2020, 93, 183-194. [CrossRef]

77. Roversi, P.F.; Binazzi, F.; Marianelli, L.; Costi, E.; Maistrello, L.; Sabbatini Peverieri, G. Searching for native egg-parasitoids of the invasive alien species Halyomorpha halys (Heteroptera Pentatomidae) in southern Europe. Redia 2016, 99, 63-70. [CrossRef]

78. Giovannini, L.; Mazza, G.; Binazzi, F.; Simom, S.; Marianelli, L.; Guerrieri, E.; Roversi, P.F.; Peverieri, G.S. Biological parameters of the egg parasitoid Ooencyrtus gonoceri. Bull. Insectol. 2020, 73, 313-319.

79. Holthouse, M.C.; Schumm, Z.R.; Talamas, E.J.; Spears, L.R.; Alston, D.G. Surveys in northern Utah for egg parasitoids of Halyomorpha halys (Stal) (Hemiptera: Pentatomidae) detect Trissolcus japonicus (Ashmead) (Hymenoptera: Scelionidae). Biodivers. Data J. 2020, 8, e53363. [CrossRef] [PubMed]

80. Sabbatini-Peverieri, G.; Mitroiu, M.D.; Bon, M.C.; Balusu, R.; Benvenuto, L.; Bernardinelli, I.; Fadamiro, H.; Falagiarda, M.; Fusu, L.; Grove, E.; et al. Surveys of stink bug egg parasitism in Asia, Europe and North America, morphological taxonomy, and molecular analysis reveal the Holarctic distribution of Acroclisoides sinicus (Huang \& Liao) (Hymenoptera, Pteromalidae). J. Hymenopt. Res. 2019, 74, 123-151. [CrossRef]

81. Joshi, N.K.; Leslie, T.W.; Biddinger, D.J. Parasitism of the Invasive Brown Marmorated Stink Bug, Halyomorpha halys (Hemiptera: Pentatomidae), by the Native Parasitoid, Trichopoda pennipes (Diptera: Tachinidae). Biology 2019, 8, 66. [CrossRef]

82. Hoelmer, K.A.; USDA, Agriculture Research Service, Beneficial Insects Introduction Research Unit, Newark, DE, USA. Personal communication, 2021.

83. Preston, C.E.; Agnello, A.M.; Hajek, A.E. Nosema maddoxi (Microsporidia: Nosematidae) in brown marmorated stink bug, Halyomorpha halys (Hemiptera: Pentatomidae), populations in the United States. Biol. Control 2020, 144. [CrossRef]

84. Simberloff, D.; Stiling, P. How risky is biological control? Ecology 1996, 77, 1965-1974. [CrossRef]

85. Pearson, D.E.; Callaway, R.M. Indirect effects of host-specific biological control agents. Trends Ecol. Evol. 2003, 18, 456-461. [CrossRef]

86. CSIRO. Australian Insect Families. Available online: http:/ / anic.ento.csiro.au/insectfamilies (accessed on 20 November 2018).

87. Stahl, J.M.; Babendreier, D.; Haye, T. Using the egg parasitoid Anastatus bifasciatus against the invasive brown marmorated stink bug in Europe: Can non-target effects be ruled out? J. Pest Sci. 2018, 91, 1005-1017. [CrossRef]

88. Lara, J.; Pickett, C.; Ingels, C.; Haviland, D.R.; Grafton-Cardwell, E.; Doll, D.; Bethke, J.; Faber, B.; Dara, S.K.; Hoddle, M. Biological control program is being developed for brown marmorated stink bug. Calif. Agric. 2016, 70, 15-23. [CrossRef]

89. Sabbatini-Peverieri, G.; Dieckhoff, C.; Giovannini, L.; Marianelli, L.; Roversi, P.F.; Hoelmer, K. Rearing Trissolcus japonicus and Trissolcus mitsukurii for biological control of Halyomorpha halys. Insects 2020, 11, 787. [CrossRef] [PubMed] 
90. Avila, G.A.; Charles, J.G. Modelling the potential geographic distribution of Trissolcus japonicus: A biological control agent of the brown marmorated stink bug, Halyomorpha halys. Biocontrol 2018, 63, 505-518. [CrossRef]

91. Hedstrom, C.; Lowenstein, D.; Andrews, H.; Bai, B.; Wiman, N. Pentatomid host suitability and the discovery of introduced populations of Trissolcus japonicus in Oregon. J. Pest Sci. 2017, 90, 1169-1179. [CrossRef]

92. Haye, T.; Moraglio, S.T.; Stahl, J.; Visentin, S.; Gregorio, T.; Tavella, L. Fundamental host range of Trissolcus japonicus in Europe. J. Pest Sci. 2020, 93, 171-182. [CrossRef]

93. Ryu, J.; Hirashima, Y. Taxonomic Studies on the Genus Trissolcus Ashmead of Japan and Korea (Hymenoptera, Scelionidae). J. Fac. Agric. Kyushu Univ. 1984, 29, 35-58. [CrossRef]

94. Jones, A.L.; Jennings, D.E.; Hooks, C.R.R.; Shrewsbury, P.M. Field surveys of egg mortality and indigenous egg parasitoids of the brown marmorated stink bug, Halyomorpha halys, in ornamental nurseries in the mid-Atlantic region of the USA. J. Pest Sci. 2017, 90, 1159-1168. [CrossRef]

95. Buffington, M.; Talamas, E.J.; Hoelmer, K.A. Team Trissolcus: Integrating taxonomy and biological control to combat the brown marmorated stink bug. Am. Entomol. 2018, 64, 224-232. [CrossRef]

96. Lara, J.R.; Pickett, C.H.; Kamiyama, M.T.; Figueroa, S.; Romo, M.; Cabanas, C.; Bazurto, V.; Strode, V.; Briseno, K.; Lewis, M.; et al. Physiological host range of Trissolcus japonicus in relation to Halyomorpha halys and other pentatomids from California. Biocontrol 2019, 64, 513-528. [CrossRef]

97. Botch, P.S.; Delfosse, E.S. Host-acceptance behavior of Trissolcus japonicus (Hymenoptera: Scelionidae) reared on the invasive Halyomorpha halys (Heteroptera: Pentatomidae) and nontarget species. Environ. Entomol. 2018, 47, 403-411. [CrossRef]

98. Bertoldi, V.; Rondoni, G.; Brodeur, J.; Conti, E. An egg parasitoid efficiently exploits cues from a coevolved host but not those from a novel host. Front. Physiol. 2019, 10. [CrossRef]

99. Saunders, T.E.; Avila, G.A.; Holwell, G.I. Pre-emptive host-specificity testing of Trissolcus japonicus (Ashmead) (Hymenoptera: Scelionidae) reveals high parasitism levels against the endemic New Zealand alpine shield bug in laboratory no-choice tests. Austral. Entomol. 2021, 60, 411-421. [CrossRef]

100. Talamas, E.J.; Johnson, N.F.; Buffington, M. Key to Nearctic species of Trissolcus Ashmead (Hymenoptera, Scelionidae), natural enemies of native and invasive stink bugs (Hemiptera, Pentatomidae). J. Hymenopt. Res. 2015, 43, 45-110. [CrossRef]

101. Clarke, A.R. The control of Nezara viridula L. with introduced egg parasitoids in Australia-A review of a landmark example of classical biological control. Aust. J. Agric. Res. 1990, 41, 1127-1146. [CrossRef]

102. Talamas, E.J.; Bon, M.C.; Hoelmer, K.A.; Buffington, M.L. Molecular phylogeny of Trissolcus wasps (Hymenoptera, Scelionidae) associated with Halyomorpha halys (Hemiptera, Pentatomidae). J. Hymenopt. Res. 2019, 73, 201-217. [CrossRef]

103. HOL. Hymenoptera Online. Available online: https://mbd-db.osu.edu/hol/taxon_name/4c0213e0-7229-4236-843a-866b72064 145 (accessed on 18 January 2021).

104. Kobayashi, T.; Cosenza, G.W. Integrated control of soybean stink bugs in the Cerrados. JARQ 1987, 20, $229-236$.

105. Correa-Ferreira, B.S.; Zamataro, C.E.O. Reproductive capacity and longevity of the egg parasitoids Trissolcus basalis (Wollaston) and Trissolcus mitsukurii Ashmead (Hymenoptera: Scelionidae). Rev. Bras. Biol. 1989, 49, 621-626.

106. Cassis, G.; Gross, G.F. Zoological Catalogue of Australia-Hemiptera: Heteroptera (Pentatonomorpha); CSIRO Publishing: Clayton, Australia, 2002.

107. Queiroz, A.P.; Taguti, E.A.; Bueno, A.F.; Grande, M.L.M.; Costa, C.O. Host preferences of Telenomus podisi (Hymenoptera: Scelionidae): Parasitism on eggs of Dichelops melacanthus, Euschistus heros, and Podisus nigrispinus (Hemiptera: Pentatomidae). Neotrop. Entomol. 2018, 47, 543-552. [CrossRef] [PubMed] 